Journal Club

Editor's Note: These short reviews of a recent paper in the Journal, written exclusively by graduate students or postdoctoral fellows, are intended to mimic the journal clubs that exist in your own departments or institutions. For more information on the format and purpose of the Journal Club, please see http://www.jneurosci.org/misc/ifa_features.shtml.

\title{
Ptfla Is a Molecular Determinant for Both Glutamatergic and GABAergic Neurons in the Hindbrain
}

\author{
Kimberly A. Aldinger and Gina E. Elsen \\ Committee on Neurobiology, The University of Chicago, Chicago, Illinois 60637 \\ Review of Yamada et al. (http://www.jneurosci.org/cgi/content/full/27/41/10924)
}

The pancreas transcription factor 1 a (Ptf1a) gene encodes a bHLH (basic helixloop-helix) transcription factor that has been shown to be required for the specification and formation of the pancreas, as well as for the generation of Purkinje cells (PCs) and interneurons in the cerebellum (Hoshino et al., 2005) and specification of dorsal interneurons in the spinal cord (Glasgow et al., 2005). Mutations in human and mouse PTF1A cause permanent neonatal diabetes mellitus associated with pancreatic and cerebellar agenesis (Hoshino et al., 2005). In the absence of Ptfla, progenitor cells required for the generation of GABAergic PCs and interneurons of the cerebellum, as well as GABAergic interneurons of the spinal cord, adopt a glutamatergic phenotype (Glasgow et al., 2005; Pascual et al., 2007). Moreover, in the dorsal telencephalon, electroporation of Ptfla produces ectopic GABA-expressing neurons with morphology and migratory behavior similar to GABAergic neurons of the cerebral cortex (Hoshino et al., 2005). Together, these studies identify Ptfla as a crucial molecular determinant of GABAergic neuronal fate.

\footnotetext{
Received Nov. 20, 2007; revised Nov. 27, 2007; accepted Nov. 28, 2007. We thank Drs. Kathleen Millen and Victoria Prince for helpful comments on this manuscript.

Correspondence should be addressed to either Kimberly A. Aldinger or Gina E. Elsen at the above address, E-mail: aldinger@uchicago.edu or gelsen@uchicago.edu.

DOI:10.1523/JNEUROSCI.5139-07.2008
}

Copyright $\odot$ 2008 Society for Neuroscience $\quad 0270-6474 / 08 / 280338-02 \$ 15.00 / 0$
In the developing cerebellar anlage, recent cell fate-mapping studies have demonstrated that Ptfla-expressing progenitor cells originate from the dorsal rhombomere 1 ( $\mathrm{r} 1)$ ventricular zone to produce cerebellar GABAergic cells, including PCs and interneurons, whereas Math1-expressing progenitor cells originate from the $\mathrm{r} 1$ rhombic lip to produce glutamatergic granule cell precursors in the cerebellar external granule layer (Hoshino et al., 2005; Wang et al., 2005). In contrast, precerebellar nuclei, consisting of mossy fiber (MF) neurons and climbing fiber (CF) neurons, are generated from the dorsal regions of multiple hindbrain rhombomeres (Wingate, 2001). A key finding of the recent study by Yamada et al. (2007) is that Ptfla is required for the generation of glutamatergic CF neurons in the precerebellar inferior olivary nucleus (ION), suggesting that although the Ptfla lineage gives rise to GABAergic neurons within the cerebellum and dorsal spinal cord, Ptflaexpressing progenitors also contribute to glutamatergic neurons of the hindbrain. This surprising result indicates that Ptfla is not simply a molecular switch determining GABAergic versus glutamatergic neuronal subtype fate, as was previously understood, but rather that it functions in a region-specific manner to specify neuronal fates.

To demonstrate that Ptfla-expressing hindbrain progenitors give rise to glutamatergic CF neurons, Yamada et al.
(2007) first generated a genetic fate map of hindbrain Ptfla-expressing progenitor cells in mice engineered to express $\beta$-galactosidase $(\beta$-gal) in these cells $\left[\right.$ Ptfla ${ }^{\text {cre/+}}$;Floxed LacZ reporter mice (R26R)]. $\beta$-gal-positive CF neurons were found in the ventrally located ION. Strikingly, these neurons were also glutaminase positive, whereas the small population of GABA-positive CF neurons within the ION was $\beta$-gal negative. Thus, GABApositive neurons in the ION are not derived from the Ptfla lineage [Yamada et al. (2007), their Fig. 1T,U (http://www. jneurosci.org/cgi/content/full/27/41/ 10924/F1)]. To investigate whether MF neurons also derive from the Ptfla lineage, the authors performed retrograde labeling of MF and CF neurons by injecting Fluorogold into the cerebellar hemisphere and vermis of adult Ptf1a $a^{\text {cre/+}}$; $R 26 R$ mice [Yamada et al. (2007), their Fig. $2 A$ (http://www.jneurosci.org/cgi/ content/full/27/41/10924/F2)]. Only CF neurons in the ION were Fluorogold negative and $\beta$-gal positive; Fluorogoldpositive MF neurons throughout the hindbrain were not $\beta$-gal positive [Yamada et al. (2007), their Fig. $2 B-P$ (http://www.jneurosci.org/cgi/content/ full/27/41/10924/F2)], confirming that CF but not MF neurons, are derived from Ptfla-expressing progenitor cells.

Studies in mice have shown that both $\mathrm{CF}$ and $\mathrm{MF}$ neurons are specified within the dorsal caudal hindbrain region around embryonic day 10.5 (E10.5)- 
E11.5. Following specification, these neurons follow a tangential and/or circumferential migration to occupy their final position (Wingate, 2001). The caudal hindbrain is divided into subregions defined along the dorsoventral axis by nonoverlapping expression patterns of transcription factors, including $\operatorname{Lm} \times 1 a$, Math1, and Ngn1. Yamada et al. (2007) show that Ptfla protein is expressed in the caudal hindbrain between the dorsal and ventral Ngn1 domains at E11.5 [Yamada et al. (2007), their Fig. 3A-I (http://www. jneurosci.org/cgi/content/full/27/41/ 10924/F3)]. To examine the migration of dorsal Ptf1a-lineage cells toward the ION, the authors followed the movement of $\beta$-gal-positive cells in Ptf1 $a^{\text {cre/+ }} ; R 26 R$ mice from E11.5 to E16.5 [Yamada et al. (2007), their Fig. 4A-L (http://www. jneurosci.org/cgi/content/full/27/41/ 10924/F4)]. They showed that at early embryonic stages, Brn3a, a marker of CF neurons, was colocalized with $\beta$-gal within the path of CF neuronal migration [Yamada et al. (2007), their Fig. 4O,Q,M (http://www.jneurosci.org/cgi/content/ full/27/41/10924/F4)]. At later stages, colocalization was also observed within the ventral ION [Yamada et al. (2007), their Figs. 4S, $U$ (http://www.jneurosci.org/cgi/ content/full/27/41/10924/F4), $5 \mathrm{~K}, \mathrm{M}$ (http://www.jneurosci.org/cgi/content/ full/27/41/10924/F5)], further confirming that ION neurons originate in the dorsal Ptfla domain.

Finally, to demonstrate that Ptfla is required for the specification of CF neurons, the authors analyzed the development of the ION in Ptfla null mice $\left(P t f 1 a^{\text {cre/cre }} ;\right.$ R26R). Neither $\beta$-gal nor Brn3a expression was observed in the ven- tromedial region of the caudal hindbrain, including the ION, in mutants at E18.5 [Yamada et al. (2007), their Fig. 5E-N (http://www.jneurosci.org/cgi/content/ full/27/41/10924/F5)], indicating a requirement for Ptfla in the development of CF neurons of the ION. No significant difference was seen in BrdU incorporation rates in the dorsal Ptfla-expressing proliferative hindbrain in younger Ptflanull mice at E10-E11.5, leading the authors to conclude that progenitors are still generated from the Ptfla domain in the absence of Ptfla function. In contrast, no ventrally migrating $\beta$-gal-positive cells were observed in E13-E16.5 Ptf1a null mutants [Yamada et al. (2007), their Figs. 4F, H-V (http://www.jneurosci.org/cgi/ content/full/27/41/10924/F4), 6A-D (http://www.jneurosci.org/cgi/content/ full/27/41/10924/F6)]. Interestingly, at E13, Brn3a- and $\beta$-gal-positive cells accumulated in lateral regions of the mutant hindbrain [Yamada et al. (2007), their Fig. $4 N, W, X$ (http://www.jneurosci.org/cgi/ content/full/27/41/10924/F4)]. At E18.5, $\beta$-gal-positive cells were observed ectopically in pontine nuclei in $\mathrm{Ptfla}$-null embryos [Yamada et al. (2007), Fig. 7A-H (http://www.jneurosci.org/cgi/content/ full/27/41/10924/F7)]; a subset of these cells also expressed Mhb2/Barhl1 (a marker for MF neurons) [Yamada et al. (2007), their Fig. 7J (http://www. jneurosci.org/cgi/content/full/27/41/ 10924/F7)]. Collectively, these remarkable experiments indicate that inactivation of Ptfla results in a change in fate from hindbrain glutamatergic ION CF into pontine MF neurons.

These findings complement another recent study demonstrating that in the ab- sence of Ptf1a function, cerebellar Ptflaexpressing progenitors in $\mathrm{r} 1$ adopt a more dorsal (Math1-expressing) fate of cerebellar granule cells (Pascual et al., 2007). Together, it seems likely that the MF neurons seen by Yamada et al. (2007) in Ptfla null mice are derived from an expanded Math1-expressing domain within the developing dorsal $\mathrm{r} 1$. This hypothesis is testable through further fate-mapping experiments to examine Math1-positive lineages (Wang et al., 2005) in Ptf1a null mice.

\section{References}

Glasgow SM, Henke RM, Macdonald RJ, Wright CV, Johnson JE (2005) Ptfla determines GABAergic over glutamatergic neuronal cell fate in the spinal cord dorsal horn. Development 132:5461-5469.

Hoshino M, Nakamura S, Mori K, Kawauchi T, Terao M, Nishimura YV, Fukuda A, Fuse T, Matsuo N, Sone M, Watanabe M, Bito H, Terashima T, Wright CV, Kawaguchi Y, Nakao K, Nabeshima Y (2005) Ptfla, a bHLH transcriptional gene, defines GABAergic neuronal fates in cerebellum. Neuron 47:201-213.

Pascual M, Abasolo I, Mingorance-Le Meur A, Martinez A, Del Rio JA, Wright CV, Real FX, Soriano E (2007) Cerebellar GABAergic progenitors adopt an external granule cell-like phenotype in the absence of Ptfla transcription factor expression. Proc Natl Acad Sci USA 104:5193-5198.

Wang VY, Rose MF, Zoghbi HY (2005) Math1 expression redefines the rhombic lip derivatives and reveals novel lineages within the brainstem and cerebellum. Neuron 48:31-43.

Wingate RJ (2001) The rhombic lip and early cerebellar development. Curr Opin Neurobiol 11:82-88.

Yamada M, Terao M, Terashima T, Fujiyama T, Kawaguchi Y, Nabeshima Y, Hoshino M (2007) Origin of climbing fiber neurons and their developmental dependence on Ptfla. J Neurosci 27:10924-10934. 